\title{
Positive education: A new look at Freedom to Learn
}

Stephen Joseph* David Murphy and John Holford

School of Education, University of Nottingham, UK

*Corresponding author. Centre for Research in Human Flourishing, School of Education, Jubilee Campus, University of Nottingham, NG8 1BB, UK. E-mail:

stephen.joseph@nottingham.ac.uk 


\begin{abstract}
Recent years have seen much interest in positive education. In this article we will show how person-centred education, like positive education, is concerned with the promotion of human flourishing. Both offer ways in which education goes beyond traditional skills and knowledge to a concern for the well-being of people. However, we argue that an awareness of the scholarship of Carl Rogers, the author of Freedom to Learn, and the originator of the personcentred approach with its contrasting ontological stance to human nature, will broaden the scope of the positive education movement to create a healthy and necessary theoretical tension in views of how positive education can be delivered.
\end{abstract}

Keywords: Positive education; Person-centred education; Human flourishing; Carl Rogers 


\section{Introduction}

Recent years have seen much interest in positive psychology applications to education and the development of the new subfield of 'positive education'. Positive education has been defined 'as education for both traditional skills and for happiness' (Seligman, Ernst, Gillham, Reivich, \& Linkins, 2009. p. 293). The term happiness is used in the definition in a broad sense; positive education programmes have been shown to foster a range of positively valued qualities including curiosity, love of learning, optimism, creativity, and social skills

(Seligman et al., 2009). In the context of rising levels of depression and anxiety among young people, those advocating positive education also see the benefit of teaching young people and young adults skills that increase their resilience, positive emotions, engagement and meaning in life. Since it was introduced, the influence of the positive education 'movement' has grown considerably. It has been taken up by a number of prestigious schools, most notably the Geelong Grammar School (Norrish, 2015).

But while positive education is seen as a relatively new initiative, its aims are similar to those of person-centred education developed by Carl Rogers several decades previously. Rogers wrote about how education could be a vehicle for helping learners become more fully functioning. Despite this, Rogers' writings on person-centred education have received little attention in the positive education literature. First, we will introduce the topic of positive education describing how its focus is on helping people flourish. Following this, we will discuss Rogers' person-centred approach, and how, despite using different terminology to that of today's scholars in positive education, it is also concerned with human flourishing.

Our aim is to discuss the confluence of the person-centred approach to education and that of positive education. We will show how person-centred education is a form of positive education, but with a contrasting view of human nature to mainstream and traditional education, which we argue mainstream positive education remans part of. Positive education, 
whilst offering a new focus on human flourishing, does not challenge traditional education with its largely teacher-centred approach. Rogers' view on education was that it was this teacher-centred approach this was itself the problem that thwarted and usurped developmental processes and stifled creativity and curiosity. In this respect, positive education, we argue, can learn from the person-centred approach to become a more radical initiative in changing lives in education, whether in schools, further or higher education.

\section{The rise of positive education}

Positive education was an idea that developed out of the positive psychology movement initiated at the turn of the new century by Seligman in his Presidential Address to the American Psychological Association (APA). Seligman's (1999) argument was that for too long psychologists had looked only at the negative side of human experience. Surely it was as important, perhaps even more so, to understand what is positive. Since these beginnings positive psychology has developed into an area of scholarship that seeks to understand and promote what is good about life. Attention has also focused on how research findings may be applied in practical settings including the development of interest in education (Joseph, 2015).

Many educationalists have welcomed the positive education movement and are seeking ways to embed positive education into the classroom, on the sports field, and throughout the curriculum in schools and universities. This is done using various positive psychology exercises such as thinking about three good things and using signature strengths in new ways (Seligman et al., 2009). Applications of positive psychology are now widely recognised in schools (Gilman, Hubener, \& Furlong, 2009) and higher education (Parks, 2013). These institutions provide an opportunity to reach young people and adults to teach 
them skills of well-being that are hoped will combat rising levels of depression and anxiety, enhance their learning and ability to think creatively.

Research has examined strategies that teachers might use in classrooms for the teaching of soft skills and well-being, to foster mental health, and promote resilience, based on positive psychology constructs such as authenticity, strengths, hope, optimism, grit, and resilience (Fineburg \& Monk, 2015; Nickerson \& Fishman, 2013; Pajares, 2001). Positive education has been eagerly adopted by the educational sector and many schools now implement some version of positive education, from introducing some aspect of positive psychology as a lesson within the curriculum, to full courses about positive psychology, or as institution wide programmes (Fineburg \& Monk, 2015). Institution wide and longer term programmes are thought to be more effective (Kibe \& Boniwell, 2015).

But while these ideas of positive education are now entering the mainstream educational agenda, the idea that education can be about more than it currently is, and play a greater role in the development of young people is not a new one. The notion that education is about more than imparting knowledge has long been recognised. Questions about the aims of education can be traced back as far as the Greek and Chinese classics (Bosanquet, 1901), as well as in more recent literature such as Newman's Idea of a University (Newman, 1910). The philosophy of education proposed by Newman considers the development of the mind to be the most important aspect of education and the particular subject itself to be of less concern. For Newman, liberal education is not to be seen 'in terms of what students learn or even of the acquisition of any particular set of skills', but rather 'in the relationship in which they come to stand to their knowledge, the manner in which they dispose of it, the perspective they have on the place of their knowledge in a wider map of human understanding.' For Newman, 'the opposite of being educated is not so much being ignorant as being one-sided, in the grip of partial knowledge, over-zealous and lacking in that calm meditativeness which 
is the mark of philosophic cultivation.' (Collini, 2012, pp. 49-50). In the modern world, such ideas seem ever more relevant.

This stream of thinking coalesced in the notion of education being about 'character'. Education, Newman held, 'implies an action upon our mental nature, and the formation of a character; it is something individual and permanent, and is commonly spoken of in connexion with religion and virtue.' (Newman, 1910: 114). This approach was a mainstream of popular wisdom in turn of the century thinking, famously in the best-selling 'self-improvement' work of Samuel Smiles (Smiles, 1910), but also in other areas for informal education of the working and middle classes (such as the games ethic) (e.g., Mangan, 1981), not to mention in the reformed 'public schools' (e.g., Collini, 1985). These ideas also nourished the early $20^{\text {th }}$ century university extra-mural and adult education (see, Goldman, 2000; Goldman, 2013), influential mid- $20^{\text {th }}$ century educationalists, such as Sir Richard Livingstone (e.g., Livingstone, 1952) and A.D. Lindsay (e,g., Lindsay, 1957), and several of the 'new universities' of the 1960s. Perhaps more prominent was their influence on practical educational projects in the independent sector: notions of character were strong in Kurt Hahn's Gordonstoun, for instance, and in cognate movements such as the United World Colleges, the International Baccalaureate (see, Peterson, 2003), and the 'Outward Bound' movement (see, Freeman, 2010).

As such, the idea that education ought to be about more than the acquisition of knowledge is not new. Positive education has simply brought back into focus these earlier discussions on the nature of education in the context of contemporary empirical research and theory in positive psychology. This renewed emphasis on the development of the positive psychological qualities of the person and the notion of education as a vehicle for helping people flourish is welcome. But even in this sense, positive education as a renewed interest arising out of developments in psychology, is not new; it is also similar to that of the person- 
centred approach of Carl Rogers, the author of the influential book Freedom to Learn. Rogers also saw education as vehicle for promoting human flourishing, and developed his ideas in the context of the then contemporary empirical research and theory in humanistic psychology. But it would not be correct to see positive education simply as a revisioning of person-centred education, as while both share an interest in human flourishing, personcentred education was based on a distinctive growth model of human nature (DeCarvalho, 1991).

\section{Looking back at Carl Rogers’ person-centred approach}

Originally a psychologist by training, in 1947 Rogers served as the President of the American Psychological Association, the same position held by Seligman fifty years later when he founded the positive psychology movement. Throughout his career Rogers was a prolific scholar, publishing numerous academic papers. In his early career working as a clinical psychologist, Rogers developed a new approach to psychotherapy that had two distinctive features.

First, the person-centred approach was focused not just on the alleviation of distress, but on helping to facilitate people to become more fully functioning. For Rogers (1963a), the concept of fully functioning described attitudes and behaviours of a person in which they were open to experience, able to live in an existential manner aware of the fluid and changing nature of experience, and trusting in themselves to know their own directions in life. By fully functioning, Rogers was describing what in modern terms would be referred to as psychological well-being, eudaimonic well-being, or human flourishing. At the time, the idea that clinical psychology and psychotherapy should be concerned with helping people flourish was an innovative proposition.

Second, at the heart of Rogers' approach was the focus on the inner resources of the person, and how under the right social conditions they will be intrinsically motivated to self- 
organise, seek out knowledge to satisfy their curiosity and to pursue goals that are meaningful to them. For Rogers, the person-centred approach was based on an image of the person that is basically trustworthy, and that humans are intrinsically motivated towards:

...development, differentiation, cooperative relationships; whose life tends to move from dependence to independence; whose impulses tend naturally to harmonize into a complex and changing pattern of self-regulation; whose total character is such as to tend to preserve himself and his species, and perhaps to move towards its further evolution (1957b: p. 201).

This ontological view of human nature is what underpins the non-directivity of the person-centred practitioner. Non-directivity is a much misunderstood concept. It does not mean no direction; rather it means the practitioner is not imposing their direction, but helping the client to find their own direction. Non-directivity is an ideological position that arises from the above fundamental assumptions of the practitioner that humans are intrinsically motivated towards personal development, differentiation, and cooperative relationships. While Rogers' influence has been greatest in the fields of one to one counselling and psychotherapy, where the person-centred approach remains widely practiced and well supported by empirical evidence (Murphy \& Joseph, 2016), it is we would argue his contributions to education which are the most significant and important for the modern world.

\section{Person-centred approach and freedom to learn}

In the same way that positive education arose out of the positive psychology movement, person-centred education developed out of the person-centred approach to psychology and psychotherapy. Early on, even as Rogers was developing his approach to psychotherapy, for 
which he is most well-known, he was beginning to turn his thoughts to the topic of teaching and learning. In Client-Centered Therapy, which Rogers published in 1951, he devoted a chapter to the topic of student-centred teaching. Later, in one of his first papers on the subject he questioned the common sense view that teaching is equivalent to learning, writing that learning may in fact be enhanced if we were able to do away with teaching, examinations, and institutionally awarded measures of competence (Rogers, 1957a).

For Rogers it seemed that educators and the public focused on teaching at the expense of learning; his argument was that it would only be when we as educators pay attention to the latter that we will find effective ways of promoting learning. For Rogers, what was important was the realness of the facilitator, their willingness to meet the student as a person, with qualities such as trust, warmth, and respect. In this way, facilitator was a better term than teacher (Rogers, 1967a).

But it was in 1969 that Rogers published his influential book Freedom to Learn (Rogers, 1969), in which, building on his earlier writings, he set out his full philosophy of education: in essence, that human beings have a natural urge to learn, that this most readily happens when the subject matter is perceived as relevant to the student, that learning involves change and as such is threatening and resisted; that learning is best achieved by doing, and that the most lasting learning takes place in an atmosphere of freedom in which students were trusted to be autonomous learners.

The goal of education for Rogers (1969), and later in his revised edition Freedom to Learn for the 80's (Rogers, 1983), was to assist people to learn to be self-determining; to take self-initiated action and to be responsible for those actions; to be able to adapt flexibly and intelligently to new problem situations; internalise an adaptive mode of approach to problems, utilizing all pertinent experience freely and creatively; cooperate effectively with others in these various activities; and work, not for the approval of others, but in terms of 
their own socialized purposes. To adopt other goals in which the teacher has a pre-determined intention that the student should change in any particular direction was seen from Rogers' person-centred perspective as contradictory to the act of nurturing self-determination.

As with therapy, Rogers' approach to education was based on the ontological view that people are born with a natural tendency towards exploration, growth, and cooperation with others - movement toward one's full potential. Such views of human nature have often been associated with a gardening metaphor in education in which the aim of the educator is to release students' innate potentials (Mintz, 2018).

Rogers did not deny that human behaviour is often destructive, but for him such behaviours were the result of hostile interpersonal environments that thwarted the innate tendency towards actualisation (Rogers, 1961, 1963b). Behaviour is consistent with the environment, institutions, communities, families and relationships in which people live, work and learn and the messages these institutions convey. For that reason, Rogers' person-centred approach is about creating a new environment for the person as characterised by the experience of feeling unconditionally accepted, empathically understood, and in genuine contact with others. When such relationship conditions exist that people feel this way, their innate tendency towards the actualisation of their potential is no longer thwarted but released so that they move towards becoming more fully functioning (Rogers, 1959).

Applied to education, these are the relationship conditions that the person-centred educator wishes to create for his or her students, and the basis for their non-directive attitude (Levitt, 2005). The person-centred educator has the "conviction that people have the right to direct their own lives and do not have to be guided into adjustment, but can do it for themselves when accepted" (Raskin, 2005; p. 346). While many educators may agree with the philosophy of Rogers, relatively few implement it in the full sense of what Rogers 
intended, and even where they would wish to do so, it is difficult because the culture of education today runs counter to his philosophy.

\section{Person-centred education today}

The person-centred approach as envisaged by Rogers remains of interest to some educators, with for example, recent theoretical scholarship examining novel applications to athletics (Nelson, Cushion, Potrac, \& Groom, 2014) and to social pedagogy (Murphy \& Joseph, 2019). Rogerian influences continue to appear periodically in education pedagogical debate. Gibbs (2013) recalls how in the mid-1980s he was 'struck by Carl Rogers' principle of learning that stated that learning is maximised when judgements by the learner (in the form of selfassessment) are emphasised and judgements by the teacher are minimised' (Gibbs, 2006). Gibbs draws on Rogers in several of his influential 53 Powerful Ideas All Teachers Should Know About series for SEDA (the Staff and Educational Development Association); he writes, for instance, that Rogers:

saw learning that was threatening to the self as a significant block, preventing people from perceiving and thinking openly. People would tend to protect their self, rather than choose to learn, with all its potential disruptions. Only when threat to the self was reduced was learning likely to proceed. For Rogers this involved a warm and supportive emotional environment, the neutral acceptance of people's views rather than aggressive challenges to them, and especially the removal of summative judgements in formal assessment (Gibbs, 2014, p. 2).

Gibbs detects 'much less emphasis on the emotional climate students study within than there used to be' (p. 3). While Rogers work recurs in discussions of higher education 
pedagogies and learning (e.g., Blackie, Case, \& Jawitz, 2000; Bleakley, 2000; Heim, 2011; Wootton, 2002), scholarship and research focused specifically on the educational application of Rogers' ideas is sparse. But that empirical evidence that does exist, shows that personcentred approaches to education are highly effective (Cornelius-White, 2007).

Educationalists - in particular those interested in theories and processes of learning have long acknowledged Rogers' writings, and his influence on the development of experiential, reflective and problem-based learning (e.g., Illeris, 2007; Jarvis, 1987, 2006; Silén, 2006) and the wider field of learner-centred forms of education (McCombs, 2012). Kolb (2014, p. xvii), for example, lists him - along with Dewey, Piaget, Vygotsky, Jung and Freire - as one of nine 'Foundational Scholars of Experiential Learning'.

However, while these latter approaches are related to more general humanistic principles espoused by Rogers, they generally move beyond Rogers' focus on non-directivity to include more directive and active teacher-centred activities. A particular example is the widely used term 'student-centred' of which Rogers is often cited as the originator, but this term is generally used in a way that belies Rogers' approach to learning (Tangney, 2014). Whereas the person-centred educator would be equipped to allow any curriculum and activities to be unfolding spontaneously in the moment and in the direction of the learners, more often the term student-centred simply means offering problem-based learning centred around the teachers pre-conceived notions of what is to be learned. Bringing a non-directive philosophy to a class of learners such that a facilitator is sensitive to the needs of individual learners, able to observe and work with the group process, not be drawn into offering teachercentred solutions, but equipped and knowledgeable enough to bring ideas, perspectives and resources when appropriate and consistent with the direction of the learners is challenging, and may require years of practice and study by a facilitator. 
It is our view that the person-centred approach to education remains a valuable philosophically based practical approach to education with contemporary significance. However, as discussed above it is an approach that is today mostly understood historically as part of an earlier movement of humanistic based educational practices, and misunderstood in its application. As such, our view is to help develop its contemporary relevance by positioning it within the more recent field of positive education.

\section{The confluence of person-centred education and positive education}

When positive psychology and then positive education were first introduced it was largely without recognition of the similar previous tradition of Rogers and other colleagues in the humanistic psychology tradition (see, Taylor, 2001). Subsequently the commonalities have been increasingly recognised (Joseph \& Murphy, 2013; Robbins, 2015). In the following section we will show: first, that the person-centred approach to education of Rogers can be considered a form of positive education because they share this same defining feature of interest in human flourishing; and second, the benefits to positive education of this repositioning of person-centred education.

\section{Person-centred education is a form of positive education}

It is clear that the motivation for, and ideas behind, the positive education movement are not new but can be found in Rogers' writings decades before. Indeed, just prior to the emergence of positive psychology, scholars such as Brockbank and McGill cited Rogers to advocate 'a move towards balance in the domains of learning' (Brockbank \& McGill, 1998, p. 47). But although Rogers' approach also emphasised the potential for education to promote the development of potential and the fully-functioning of the individual, his work is rarely cited in the positive education literature. 
Remarkably, there is not one reference to Rogers in the seminal paper on positive education by Seligman et al (2009), or in any of the 35 chapters in Gilman, Hubener and Furlong's (2009) Handbook of Positive Psychology in Schools, and only one reference in Parks' (2013) edited 17 chapter book Positive Psychology in Higher Education. It is a matter of speculation why the work of Rogers is so notably absent in the positive education literature.

The one reference in the book by Parks (2013) is in the chapter by Magyar-Moe (2013) in her chapter 'Incorporating positive psychology content and applications into various psychology courses' where she references Rogers (1957c) paper on the necessary and sufficient conditions in the context of explaining how students who are learning counselling can be taught about positive psychology. The mention is however brief. She writes that 'Positive empathy can also be taught to supplement training in general empathy' (p. 26). While her point that empathic responses need to attend to both the positive and negative is a good one, this was in fact Rogers' conception of empathy.

Rogers was clear in his writings that the task of the therapist was to respond to the total phenomenological world of the client, not just one portion. Magyar-Moe's chapter, however, shows some awareness of Rogers' work in contrast to the many other chapters and writings on positive education, where in many instances the conceptual issues and challenges now discussed by positive psychologists in education have already been addressed by Rogers and his colleagues.

It is this relative absence of recognition to Rogers' work and person-centred education within the positive education literature that has led us to make the case that the personcentred approach to education is a form of positive education. We wish to see this historical lineage more widely recognised and for new scholars and researchers in positive education to be aware of the person-centred approach. However, it is not only for historical recognition; 
we also think that Rogers' work remains of great contemporary significance. The part of Rogers' work that we think is most significant is his ontological stance, and how this stands in contrast to that of positive education.

\section{How positive education can benefit from the person-centred approach}

Person-centred education and positive education have a shared focus on human flourishing. But what makes person-centred education different to positive education is its clear ontological stance that people are their own best experts, and the resultant hypothesis that through a certain type of relationship people will be self-determining and move in autonomous and socially constructive directions. In contrast, positive education is a smorgasbord of methods, lacking in any single underpinning ontological approach. In this respect, positive education cannot be considered to be person-centred, but person-centred education can be thought of as a form of positive education,

The heart of Rogers' approach is the focus on the inner resources of the person, be they psychotherapy clients or students, and how under the right social conditions they will be intrinsically motivated to self-organise, seek out knowledge to satisfy their curiosity and to pursue goals that are meaningful to them. This ontological position and a non-directive attitude is not shared by positive psychology which has no single view of human nature shared by all its theoreticians and practitioners, but continues to operate largely from a position of directivity and teacher-centredness.

Ontologically, positive education programmes mostly seem to proceed in ways that are largely consistent with mainstream and traditional views of education in which the teacher is possessor of knowledge to be imparted to the student who is a recipient, within a hierarchical structure in which the teacher as a representative of the power structure determines the content and direction of the curriculum. This is rarely made explicit in the writings of positive educationalists, but can be easily inferred from the writings about the 
programmes. If they were based around non-traditional ontological stances in which it is the student who is expert on what direction to move, and thus promote non-directive and studentcentred ways of working, that would need to be made explicit given how unusual it is. Typically, ideas around resilience and grit that are being introduced into schools are done so in a teacher-centred way as opposed to one in which it is hoped to release innate potential of the young person (Mintz, 2018).

As such, positive education approaches are not always implemented as an end in themselves but as a means to an end where that is to further academic attainment. For example, the idea of character education is considered as a means to students doing better in conventional terms rather than it being considered the outcome of an educational process (Heckman, Humphries \& Kautz, 2014). Indeed, these approaches to character education are used in all sectors and there has been research into developing character that is desirable in leading to improving employability (Birdwell, Sott, \& Reynolds, 2015). However, a different study of social action and character development intended to improve employability and attainment found that pupils engaging in uniformed social action services (i.e., The Scout Association, Fire Cadets, Sea Cadets or St John Ambulance) did not improve attainment (Gorard et al, 2016). These studies highlight that whilst positive education can be useful in broadening curricular activities it is also the case that often this is done in order to arrive at the same traditional outcome with academic attainment being considered the primary goal for education.

There are of course exceptions in the positive education literature in which authors do offer what seem to be approaches consistent with person-centred education, in which intrinsic motivation of the learner and their relationship with the facilitator is emphasised. An example is the work of Larson and Pearce Dawes (2015) who discuss the ability of professionals in education to cultivate young people's intrinsic motivation and how to support their sense of 
agency. But such writings are an exception in the positive education literature and while adopting what seems like a similar ontological stance as person-centred educationalists, they do not cite Rogers in this regard or explicitly recognise that the approach they are taking is consistent with the already established tradition of the person-centred approach.

As such, the person-centred approach to education seems to remain as radical a proposition as it did over fifty years ago. It is in this way that the use of the gardening metaphor describes the person-centred approach, and its underpinning meta-theoretical framework to help guide educational practice, and what makes it distinct from mainstream positive education - which by contrast employs directive methods that imply the conviction that people do not have the right to direct their own lives. In essence positive education adopts more of the metaphor of the car mechanic than the gardener, but it does so implicitly.

Seen from the person-centred approach, the idea put forward that positive education is a corrective to the unprecedented rise in depression and anxiety in young people and other problems (Seligman et al., 2009; Kibe \& Boniwell, 2015), is using fuel to stem the fire. Both positive education and person-centred education are committed to fostering achievement, but they take different stances towards how that is done; it is the difference between using 'the personal for the sake of the functional' as opposed to 'the functional is used for the sake of the personal', as discussed by Fielding (2006, p. 302). By the former Fielding means using human relations instrumentally in a way that is ultimately totalitarian, and in the latter, developing genuine human relationships. Positive education by working alongside traditional education rather than challenging it, and using the same methods of teaching, condones the political and social systems that disempower young people and young adults that have given rise to the problems.

In contrast, for Rogers, the person-centred approach is about genuine human relations in which the responsibility for learning is shared between student and facilitator, students 
develop their own programme of learning, in the expectation that given the freedom and the facilitative environment they will move in the most constructive directions for themselves. What we are describing here is an ontological stance towards education in which a person's intrinsic motivation is cultivated, and their flourishing as human beings arises, not by teaching them about resilience, grit, and so on, but by developing autonomy, agency, and self-understanding through the process of learning to learn.

In this respect we would agree with many of the concerns from some scholars about the 'dangerous' rise of therapeutic education (Smith, 2002; Ecclestone \& Hayes, 2008). Their claim is that education in schools has become too therapeutically oriented with an emphasis on social and emotional development. They are critical of what they refer to as the therapeutic ethos and how it offers a cultural vocabulary and underlying assumptions, and to an extent we would agree with their argument in respect of how positive education has been developed and implemented to promote mechanistic, behavioural, and cognitive approaches to developing human flourishing.

However, we have argued that it is possible to promote a climate of human flourishing without compromising on educational attainment goals. The question is how these dual goals of learning about subjects and learning about oneself are managed. As Seligman et al (2009) wrote 'I am all for accomplishment, success, literacy, and discipline; but imagine if schools could, without compromising either, teach both the skills of well-being and the skills of achievement' (pp. 293-294). It is not hard to imagine; for that was the accomplishment of Rogers (1969) in his development of person-centred education, and as Fielding (2006) has more recently discussed, these do not have to be competing goals. The question is whether to use the personal for the sake of the functional or the functional for the sake of the personal. From the ontological position represented by the person-centred approach, well-being and achievement are not at the expense of the other; success in learning about oneself is integral 
to success in learning about the world, and in life's achievements. Education can be understood as being about the full development of the person and not merely the functional acquisition of facts or the use of memory to recall these facts. In the person-centred approach one is not at the expense of the other as both are so closely intertwined.

\section{Conclusion}

Rogers (1967b) wrote in the introduction to his paper $A$ plan for self-directed change in an educational system that "The title which I first chose for this paper was "A practical Plan for Educational Revolution." I felt, though, that this might offend and antagonize too many people. Why is there need for a revolution in education?' (p. 717). We would argue that while positive education has reintroduced some of the ideas back into the educational agenda about the promotion of well-being in young people and adults, the need for revolution in the way envisaged by Rogers remains. We have argued that person-centred education is a form of positive education, insofar as both emphasise the promotion of human flourishing, but it places what we see as a much needed new stake firmly in the ground to draw attention to, and create a tension with, the otherwise implicitly accepted ontological stance of mainstream positive education.

Contemporary positive education, despite its intentions to promote well-being, remains rooted in an ontological stance in which people are irrational, unsocialized, and destructive, and needing external direction; in contrast to person-centred education which sees people as basically rational, socialized, and constructive. Whether one agrees with Rogers' ontological stance or not is unimportant, the point is that educationalists need to be aware of their own ontological stance and that all interventions are based on some understanding of human nature. 
For the person-centred educationalist the introduction of positive education takes a step towards a necessary revolution but it stops well short of promoting a curriculum change that would be fully respectful of learners' self-determination. For the person-centred educator, the goal of education must be to produce fully functioning people, who are open to experience, adopt an existential way of living, and trust in themselves to know their directions. The person-centred approach is an alternative powerful pedagogy, in which the person is learning to be themselves, to actualise their potential, in ways that seem increasingly important for the world today (O'Hara, 2007).

While positive psychology has been seen as a new idea, Rogers described the characteristics of the fully functioning person consistent with the notions of human flourishing now advocated by positive psychologists; but unlike positive psychology Rogers' approach was one that challenged authoritarian teacher-centred structures. Unlike positive education which is about introducing new teaching alongside existing curricula, personcentred education is about widespread changes to how existing curricula are constructed and taught.

In this broader sense, there is much that educationalists more generally can learn from the Rogerian philosophy, such as how best to nurture authenticity and autonomous learning (Henri, Morrell, \& Scott, 2017). Positive education initiatives have been criticised for instilling values in young people that are determined by the educators, and politicians, and which run counter to those of the parents; but all educational initiatives impose values, from along the spectrum represented by the traditional mode at one end, at which the teacher is possessor of knowledge and authority, to the other, person-centred end of the spectrum, at which self-determination of the student is prized above all else. Ultimately, such values are based on notions of human nature which are as yet beyond empirical verification, and are choices made by the educator. In this regard, educators must not be the puppets of politicians, 
but they must also stand their ground for what they believe even when this goes against popular opinion.

For many educationalists these may be brand new ideas that challenge them to rethink their approach to teaching and learning. For others, however, these ideas will sound familiar. Rogers (1977) wrote how the humanistically oriented teachers feels like an alien within the conventional system, with their wish to share responsibility for the content and direction of the curriculum, and to help students find their own programme of learning. Over four decades later, the humanistic approach remains just as outside the mainstream of education, if not more so, but seen as a form of positive education we hope it will garner new interest. 


\section{References}

Blackie, M. A. L., Case, J. M., \& Jawitz, J. (2000). Student-centredness: the link between transforming students and transforming ourselves. Teaching in Higher Education, 15(6), 637-646. doi:10.1080/13562517.2010.491910

Bleakley, A. (2000). Adrift Without a Life Belt: Reflective self-assessment in a post-modern age. Teaching in Higher Education, 5(4), 405-418. doi:10.1080/713699179

Birdwell, J., Scott, R. \& Reynolds, L. (2015). Service Nation 2020. London: Demos.

Bosanquet, B. (1901). The Education of the Young in the republic of Plato (Stereotyped ed.). Cambridge: Cambridge University Press.

Brockbank, A., \& McGill, I. (1998). Facilitating Reflective Learning in Higher Education. Buckingham: SRHE \& Open University Press.

Collini, S. (1985). The Idea of 'Character' in Victorian Political Thought. Transactions of the Royal Historical Society, Fifth Series 35: 29-50.

Collini, S. (2012). What Are Universities For? London: Penguin.

Cornelius-White, J. (2007). Learner-centered teacher-student relationships are effective: A meta-analysis. Review of Educational Research, 77(1), 113-143.

DeCarvalho, R. J. (1991). The growth hypothesis in psychology: The humanistic psychology of Abraham Maslow and Carl Rogers. EMText: San Francisco.

Ecclestone, K. \& Hayes, D. (2008). The Dangerous Rise of Therapeutic Education. London, Routledge.

Ecclestone, K., \& Hayes, D. (2009). Changing the subject: the educational implications of developing emotional well-being. Oxford Review of Education, 35(3), 371-389.

Fielding, M. (2006). Leadership, radical student engagement and the necessity of personcentred education. International Journal of Leadership in Education, 9(4), 299-313. 
Fineburg, A. C., \& Monk, A. (2015). Different approaches to teachign positive psychology. In S. Joseph (Ed.), Positive psychology in practice: Promoting human flourishing in work, health, education, and everyday life (pp. 267-278). Hoboken, NJ: John Wiley \& Sons.

Freeman M. (2010). From 'character-training' to 'personal growth': the early history of Outward Bound 1941-1965. History of Education: 1-23.

Furlong, M. J., Gilman, R., \& Huebner, E. S. (Eds.). (2009). Handbook of positive psychology in schools. Routledge.

Gibbs, G. (2006). How assessment frames student learning. In C. Bryan \& K. Clegg (Eds.), Innovative Assessment in Higher Education (pp. 23-37). Abingdon: Routledge.

Gibbs, G. (2013). Learning by Doing: A Guide to Teaching and Learning Methods (Online ed.). Oxford: Oxford Centre for Staff and Learning Development, Oxford Brookes University.

Gibbs, G. (2014). 53 Powerful Ideas All Teachers Should Know About, No. 25: Fear and anxiety are the enemies of learning. London: SEDA.

Goldman, L. (2000) Intellectuals and the English working class 1870-1945: the case of adult education. History of Education 29: 281-300.

Goldman, L. (2013) The Life of R.H. Tawney: socialism and history, London: Bloomsbury Academic.

Gorard, S., See, B. H., Siddiqui, N., Smith, E., \& White, P. (2016). Youth social action trials: Youth United: Evaluation report and executive summary. Educational Endowment Foundation. Available at, https://educationendowmentfoundation.org.uk/public/files/Support/Links/Campaig ns/Evaluation Reports/EEF Project Report Youth Social Action Trials.pdf 
Hayes, D. (2003). The Changed Nexus Between Work and Education. In: J. Lea et al. (eds.) Working in Post-Compulsory Education. Maidenhead: Open University Press.

Heckman, J. J. \& Kautz T. (2014). Fostering and measuring skills: Interventions that improve character and cognition. In Heckman, J. J., Humphries, J. E., \& Kautz T. (Eds.), The Myth of Achievement Tests: The GED and the Role of Character in American Life (pp. 341-430). Chicago, IL: University of Chicago Press.

Heim, C. (2011). Tutorial facilitation in the humanities based on the tenets of Carl Rogers. Higher Education, 63(3), 289-298. doi:10.1007/s10734-011-9441-z

Henri, D. C., Morrell, L. J., \& Scott, G. W. (2017). Student perceptions of their autonomy at University. Higher Education, DOI 10.1007/s10734-017-0152-y

Illeris, K. (2007). How We Learn: Learning and non-learning in school and beyond. Abingdon: Routledge.

Jarvis, P. (1987). Adult Learning in the Social Context. Beckenham: Croom Helm. Jarvis, P. (2006). Towards a Comprehensive Theory of Human Learning. Abingdon: Routledge.

Joseph, S., \& Murphy, D. (2013). Person-centered theory encountering mainstream psychology: Building bridges and looking to the future. In J. H. D. Cornelius-White, R. Motschnig-Pitrik., \& M. Lux (Eds.), Interdisciplinary handbook of the personcentered approach (pp. 213-226). Springer, New York, NY.

Joseph, S. (2015), (Ed), Positive psychology in practice: Promoting human flourishing in work, health, education, and everyday life. Hoboken, NJ: John Wiley \& Sons.

Kibe, C., \& Boniwell, I. (2015). Teachign well-being nd resilience in primary and secondary school. In S. Joseph (Ed.), Positive psychology in practice: Promoting human flourishing in work, health, education, and everyday life (pp. 297-312). Hoboken, NJ. John Wiley \& Sons. 
Kolb, D. A. (2014). Experiential Learning: Experience as the Source of Learning and Development. Upper Saddle River, NJ: Pearson Education.

Larson, R. W., \& Pearce Dawes, N. (2015). Cultivating adolescents' motivation. In S. Joseph (Ed.), Positive psychology in practice: Promoting human flourishing in work, health, education, and everyday life (pp. 313-328). Hoboken, NJ. John Wiley \& Sons.

Levitt, B. E. (Ed.), (2005). Embracing non-directivity: Reassessing person-centered theory and practice in the $21^{\text {st }}$ century. Ross-on-Wye, England: PCCS Books.

Lindsay, A. D. (1957). Selected Addresses. Boot, Holmrook, Cumberland: E.V. Lindsay. Livingstone, R.W. (1952). Education and the Spirit of the Age, Oxford: Clarendon Press. McCombs, B. L. (2013). The learner-centered model: From the vision to the future. In J. H. D. Cornelius-White, R. Motschnig-Pitrik., \& M. Lux (Eds.), Interdisciplinary Applications of the Person-Centered Approach (pp. 83-113). Springer, New York, NY.

Magyar-Moe, J. L. (2013). Incorporating positive psychology content and applications into various psychology courses. In A. C Parks (Ed.), Positive psychology in higher education (pp. 24-29). Routledge. London.

Mangan, J. A. (1981). Athleticism in the Victorian and Edwardian Public School: The Emergence and Consolidation of an Education Ideology, Cambridge: Cambridge University Press.

Mintz, A. I. (2018). The present, past, and future of the gardening metaphor in education. Oxford Review of Education, 44(4), 414-424.

Murphy, D., \& Joseph, S. (2016). Person-centered therapy: Past, present, and future orientations. In In D. J. Cain, K. Keenan., \& S. Rubin (Eds.), Humanistic psychotherapies: Handbook of research and practice (pp. 185-218), Second Edition. Washington, DC: APA. 
Murphy, D., \& Joseph, S. (2019). Contributions from the person-centred experiential approach to the field of social pedagogy. Cambridge Journal of Education, 49 (2), 181-196, DOI: 10.1080/0305764X.2018.1488946.

Nelson, L., Cushion, C. J., Potrac, P., \& Groom, R. (2014). Carl Rogers, learning and educational practice: Critical considerations and applications in sports coaching. Sport, Education and Society, 19(5), 513-531.

Newman, J. H. (1910). The Idea of a University Defined and Illustrated (I) In Nine Discourses Delivered to the Catholics of Dublin (II) In Occasional Lectures and Essays Addressed to the Members of the Catholic University. London: Longmans, Green, and Co.

Nickerson, A. B., \& Fishman, C. E. (2013). Promoting mental health and resilience through strength-based assessment in US schools. Educational and Child Psychology, 30(4), 7-17.

Norrish, J. M. (2015). Positive education: The Geelong Grammar School journey. Oxford Positive Psychology Series.

O'Hara, M. (2007). Psychological Literacy for an Emerging Global Society: Another look at Rogers' "persons of tomorrow” as a model. Person-Centered \& Experiential Psychotherapies, 6(1), 45-60.

Pajares, F. (2001). Toward a positive psychology of academic motivation. The Journal of Educational Research, 95(1), 27-35.

Parks, A. C. (Ed.), (2013). Positive psychology in higher education. Routledge. London. Peterson, A. D. C. (2003). Schools across Frontiers: The Story of the International Baccalaureate and the United World Colleges, Chicago: Open Court. 
Raskin, N. J. (2005). The non-directive attitude. In B. Levitt (Ed.), Embracing nondirectivity: Reassessing person-centered theory and practice in the $21^{\text {st }}$ century (pp. 329-347). Ross-on-Wye: PCCS Books.

Robbins, B. D. (2015). Building bridges between humanistic and positive psychology. In S. Joseph (Ed.), Positive psychology in practice: Promoting human flourishing in work, health, education, and everyday life, (pp. 31-45). Wiley: Hoboken, NJ.

Rogers, C. R. (1951). Client-Centred Therapy: Its Current Practice, Implications and Theory. Boston: Houghton Mifflin.

Rogers, C. R. (1957a). Personal thoughts on teaching and learning. Merrill-Palmer Quarterly, 3(4), 241-243.

Rogers, C. R. (1957b). A note on the nature of man. Journal of Consulting Psychology, 4(3), 199-203.

Rogers, C. R. (1957c). The necessary and sufficient conditions of therapeutic personality change, Journal of Consulting Psychology, 21, 95-103.

Rogers, C.R. (1959). A theory of therapy, personality and interpersonal relationships, as developed in the client-centered framework. In S. Koch (Ed.), Psychology: A study of science, Vol. 3: Formulations of the person and the social context (pp. 184-256). New York: McGraw-Hill.

Rogers, C. R. (1961). On Becoming a Person. Boston: Houghton Mifflin.

Rogers, C. R. (1963a). The concept of the fully functioning person. Psychotherapy: Theory, Research \& Practice, 1(1), 17 - 26.

Rogers, C. R. (1963b). The actualizing tendency in relation to "motives" and to consciousness. In M. R. Jones (ed.), Nebraska Symposium on Motivation, Vol. 11, Lincoln, NE, University of Nebraska Press, pp. 1-24. 
Rogers, C. R. (1967a). The interpersonal relationship in the facilitation of learning. In R. Leeper. (Ed.), Humanizing Education. Alexandria, VA: Association for Supervision and Curriculum Development, 1-18.

Rogers, C. R. (1967b). A plan for self-directed change in an educational system. Educational Leadership, 24(8), 717-731.

Rogers, C. R. (1969). Freedom to Learn. Columbus, OH: Charles E. Merrill.

Rogers, C. R. (1977). The politics of education. Journal of Humanistic Education, 1(1), 6-22.

Rogers, C. R. (1983). Freedom to Learn for the 80's. Charles E. Merril Pub. Co., Columbus, Ohio.

Seligman, M. E. P. (1999). The president's address. American Psychologist, 54, 559562.

Seligman, M. E., Ernst, R. M., Gillham, J., Reivich, K., \& Linkins, M. (2009). Positive education: Positive psychology and classroom interventions. Oxford review of education, 35(3), 293-311.

Silén, C. (2006). The Tutor's Approach in Base Groups (PBL). Higher Education, 51(3), 373-385. doi:10.1007/s10734-004-6390-9.

Smiles, S. (1910). Self-Help with Illustrations of Conduct and Perseverance, London: John Murray.

Smith, R. (2002). Self-Esteem: The Kindly Apocalypse. Journal of Philosophy of Education, $36(1), 87-100$.

Tangney, S. (2014). Student-centred learning: a humanist perspective. Teaching in Higher Education, 19(3), 266-275.

Taylor, E. (2001). Positive psychology and humanistic psychology: A reply to Seligman. Journal of Humanistic Psychology, 41(1), 13-29. 
Wootton, S. (2002). Encouraging Learning or Measuring Failure? Teaching in Higher Education, 7(3), 353-357. doi:10.1080/13562510220144833 